\title{
Thalidomide protects mice against LPS-induced shock
}

A.L. Moreira ${ }^{1,2}$, J. Wang ${ }^{1}$, E.N. Sarno ${ }^{2}$ and G. Kaplan ${ }^{1}$

\author{
${ }^{1}$ Laboratory of Cellular Physiology and Immunology, \\ The Rockefeller University, New York, NY, USA \\ ${ }^{2}$ Setor de Hanseníase, Fundação Oswaldo Cruz, \\ Rio de Janeiro, RJ, Brasil
}

\author{
Correspondence \\ A.L. Moreira \\ The Rockefeller University \\ 1230 York Avenue \\ New York, NY 10021 \\ USA \\ Fax: (212) 327-8875 \\ E-mail: \\ moreira@rockvax.rockefeller.edu \\ Research supported in part by \\ the U.S. Public Health Service \\ (Nos. Al-33124 and Al-07012 to \\ G. Kaplan). A.L. Moreira is the \\ recipient of a Villares fellowship. \\ $\ldots \ldots \ldots \ldots \ldots \ldots \ldots$
}

Received December 19, 1996 Accepted August 5, 1997

Ac................................

\begin{abstract}
Thalidomide has been shown to selectively inhibit TNF- $\alpha$ production in vitro by lipopolysaccharide (LPS)-stimulated monocytes. TNF- $\alpha$
\end{abstract}

Key words

- Endotoxic shock

- Thalidomide

- Cytokines

- Inflammation

\section{Introduction}

Injection of lipopolysaccharide (LPS) into experimental animals induces a massive production of tumor necrosis factor- $\alpha$ (TNF- $\alpha$ ) and other endogenous inflammatory mediators which are associated with pathological manifestations such as fever, anorexia, malaise and shock $(1,2)$. The role of TNF- $\alpha$ in the pathogenesis of endotoxic shock has been extensively investigated. Injection of recombinant TNF- $\alpha$ into experimental animals mimics the pathological alterations found in endotoxic shock (3). Monoclonal antibodies directed against TNF- $\alpha$ prevent lethality in the mouse (4) and in the primate models (5), when given prior to LPS challenge. Further evidence for the role of TNF- $\alpha$ in the pathogenesis of endotoxic shock has emerged from studies with TNF- $\alpha$ receptor knock-out mice, which are unresponsive to TNF- $\alpha$, and are thereby protected from endotoxic shock (6). Other LPS-induced cytokines, such as interleukin-1 (IL-1) and interferon gamma (IFN$\gamma)$, have also been implicated in the pathogenesis of endotoxic shock (2). Administra- 
tion of IL-1 receptor antagonist has been shown to abolish lethality in experimental models $(7,8)$. In addition, IFN- $\gamma$ receptor knock-out mice are resistant to lethal doses of LPS (9). This suggests an interactive cytokine network or cascade of effector molecules contributing to the pathophysiology of endotoxic shock syndrome.

The development of therapies directed towards the inhibition of TNF- $\alpha$ production has been an important goal in improving the management of endotoxic shock and TNF- $\alpha$-induced pathology. Drugs such as pentoxifylline $(10,11)$, hydrazine sulfate (12), and some metalloprotease inhibitors (13) have been shown to inhibit TNF- $\alpha$ production in vitro and in vivo; this inhibition is associated with protection from lethal doses of LPS injected into experimental animals.

Thalidomide, $\alpha$-N-phthalimidoglutarimide, has been shown to selectively inhibit $\mathrm{TNF}-\alpha$ production in vitro in human peripheral blood-derived monocytes stimulated with LPS or mycobacterial agonists $(14,15)$. In the present study we utilized the murine model of endotoxic shock to investigate the effects of thalidomide on LPS-induced cytokine production in vivo and on animal survival after endotoxic shock.

\section{Material and Methods}

Mice

Female B6D2/F1 (C57/b6 x DBA2) mice (Jackson Laboratories, Bar Harbor, ME), 7 9 weeks old, were used in the experiments. Mice were housed in group cages at the Animal Research Center, Rockefeller University.

\section{Reagents}

Thalidomide was supplied by Celgene Corporation (Warren, NJ). The drug was dissolved in sterile dimethylsulfoxide (DMSO) (Sigma Chemical Co., St. Louis,
MO) at $50 \mathrm{mg} / \mathrm{ml}$ (stock concentration), diluted in acidified pyrogen-free saline to the desired concentration and used immediately. The final concentration of DMSO was $2 \%$. Lipopolysaccharide B from E. coli 026:B6 (Difco Laboratories, Detroit, MI) was reconstituted in saline to give a stock concentration of $1 \mathrm{mg} / \mathrm{ml}$ and stored at $-20^{\circ} \mathrm{C}$ until use.

\section{Experimental design}

Thalidomide was administered intraperitoneally to the mice at two doses of $200 \mathrm{mg} /$ $\mathrm{kg}$ in saline with $2 \%$ DMSO (unless otherwise specified) $18 \mathrm{~h}$ and $2 \mathrm{~h}$ prior to LPS challenge. This regimen of thalidomide administration induced sedation of the mice 30 min after the drug had been injected into the peritoneal cavity. Control animals received injections of saline with $2 \%$ DMSO. LPS at doses ranging from 100 to $350 \mu$ g per mouse was injected intravenously into a lateral tail vein at the beginning of the experiment to characterize the dose-response effect of LPS. For blood collection by cardiac puncture mice were anesthetized with a solution of ketamine (44 mg/kg) (Aveco Co., Inc., Fort Dodge, $\mathrm{IO}$ ) and xylazine $(5 \mathrm{mg} / \mathrm{kg}$ ) (Rompum, Mobay Corp., Shawnee, KS). Blood was collected at regular intervals from $15 \mathrm{~min}$ to $12 \mathrm{~h}$ after LPS injection. Serum was separated and stored at $-80^{\circ} \mathrm{C}$ until assay. Livers and spleens were obtained immediately after cardiac puncture and processed for RNA extraction (see below).

\section{Serum TNF- $\alpha$ level determination}

Serum TNF levels were measured by the cytotoxicity assay described by Fisch and Gifford (16). Briefly, the murine fibrosarcoma cell line L929B was used as the target for TNF-induced cytotoxicity. Cells were seeded at $5 \times 10^{4}$ cells/well in a 96-well flat bottom plate (Costar, Inc., Cambridge, MA) in RPMI 1640 (Gibco, Grand Island, NY) 
supplemented with 5\% fetal calf serum (FCS) (Atlanta Biologicals, Norcross, GA) (culture medium) and incubated overnight at $37^{\circ} \mathrm{C}$ in a $5 \% \mathrm{CO}_{2}$ humidified incubator. Sequential two-fold dilutions of the sera were made in culture medium containing $2 \mu \mathrm{g} / \mathrm{ml}$ actinomycin-D (Calbiochem-Boehring Corp., La Jolla, CA). One hundred $\mu \mathrm{l}$ of each dilution was added to wells containing a confluent monolayer of L929B cells. After 18-20 h of incubation, plates were fixed and stained with $0.2 \%$ crystal violet in $2 \%$ ethanol solution. Plates were washed and analyzed with an ELISA plate reader (Dynatech Laboratories, Chantilly, VA) at $570 \mathrm{~nm}$. TNF titer (U/ $\mathrm{ml}$ ) was defined as the inverse of the dilution that caused $50 \%$ destruction of the monolayer. Serum TNF- $\alpha$ levels were also evaluated by ELISA (see below), and the correlation coefficient between the TNF- $\alpha$ levels measured by ELISA or bioassay was $r=0.93$ and $\mathrm{P}=0.0001$.

\section{Cytokine determination}

TNF- $\alpha$, IFN- $\gamma$, GM-CSF, IL-6, and IL-10 levels were measured with commercial ELISA kits for these cytokines (Endogen, Inc., Boston, MA). Kits were used according to manufacturer specification.

\section{Northern blots}

Total cellular RNA was obtained from $0.1 \mathrm{~g}$ each of liver or spleen of LPS-injected mice treated with thalidomide or DMSO. Tissues were homogenized in $2 \mathrm{ml}$ of RNAzol B (Cinna/Biotecx Lab., Inc., Houston, TX) and RNA was extracted according to manufacturer instructions. RNA was size fractionated by agarose/formaldehyde gel electrophoresis and transferred onto a nylon membrane (Biorad, Hercules, CA). Membranes were hybridized as described elsewhere (15) with ${ }^{32} \mathrm{P}$-labeled random-primed probes specific for murine TNF- $\alpha$ (1.1-kb EcoRI fragment), IL-1ß (2.0-kb BamHI-
HindIII fragment), IL-10 (1.34-kb BamHI fragment), IFN- $\gamma(0.7-\mathrm{kb}$ PstI fragment) (ATCC, Rockville, MD) and B-actin (1.2-kb EcoRI-XhoI fragment) (17). Densitometry was performed with a Phosphorimager (Molecular Dynamics, Sunnyvale, CA) and results are reported as density units.

\section{Statistical analysis}

The paired $t$-test and the Fisher exact ptest were used when appropriate.

\section{Results}

\section{Effect of thalidomide on TNF- $\alpha$ production in vivo}

LPS was administered intravenously to mice and TNF- $\alpha$ production was induced in a dose-dependent manner. Serum TNF- $\alpha$ levels peaked at $1.5 \mathrm{~h}$ after LPS injection and were no longer detectable after $5 \mathrm{~h}$ (Figure 1A). There was no subsequent peak of TNF$\alpha$, in accordance with previous observations
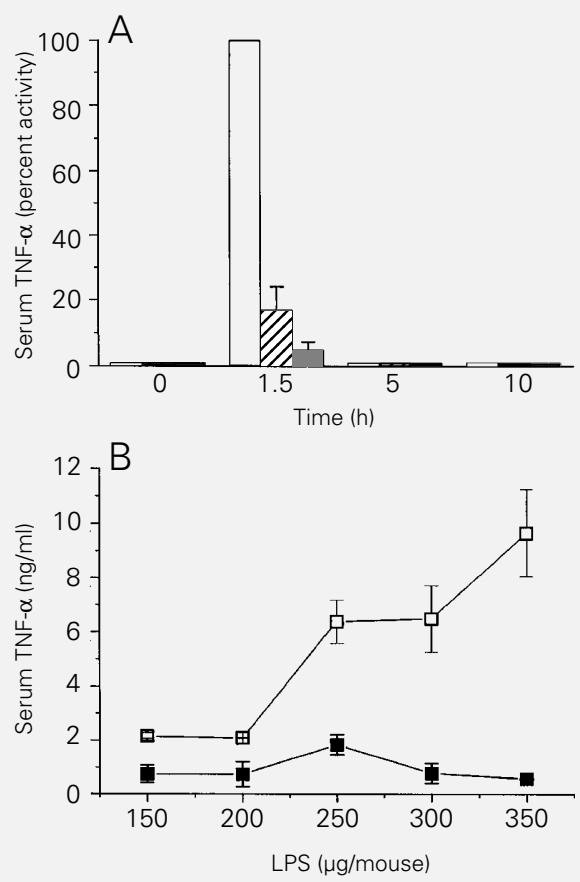

Figure 1 - TNF- $\alpha$ levels in serum of B6D2/F1 mice in response to LPS. $A, 100 \mu \mathrm{g}$ of LPS was injected into mice by the intravenous route (iv) (open bars). Thalidomide was administered $18 \mathrm{~h}$ and $2 \mathrm{~h}$ before LPS at $100 \mathrm{mg} / \mathrm{kg}$ (hatched bars) or at $200 \mathrm{mg} / \mathrm{kg}$ (filled bars). Blood was collected at different time intervals after LPS administration (20 mice per group). $B$, LPS dose response mice were injected iv with different LPS concentrations (open squares), and thalidomide was administered to mice at 2 doses of $200 \mathrm{mg} / \mathrm{kg}$ as described above (filled squares). Blood for TNF- $\alpha$ evaluation was collected $1.5 \mathrm{~h}$ after injection (4 mice per data point). Results are reported as means \pm SD 
(18). The administration of $100 \mathrm{mg} / \mathrm{kg}$ thalidomide $2 \mathrm{~h}$ before LPS injection resulted in 60-70\% inhibition of TNF- $\alpha$ production (19). When the animals were pre-loaded with thalidomide using two doses of $100 \mathrm{mg} / \mathrm{kg}$ thalidomide, $18 \mathrm{~h}$ and $2 \mathrm{~h}$ before the injection of $100 \mu \mathrm{g}$ of LPS, the reduction in TNF- $\alpha$ levels reached $83 \pm 7 \%$. This effect was improved further by administration of two doses of $200 \mathrm{mg} / \mathrm{kg}$ thalidomide, now giving an inhibition of $95 \pm 2.3 \%$ in TNF- $\alpha$ levels, thus demonstrating a dose-dependent effect (Figure 1A). Thalidomide given together or after the LPS challenge did not affect the production of TNF- $\alpha$ in vivo (data not shown). Regardless of the dose of LPS used there was a marked reduction in the production of TNF- $\alpha$ in mice treated with two doses of $200 \mathrm{mg} / \mathrm{kg}$ thalidomide (Figure 1B). However, thalidomide treatment did not inhibit TNF- $\alpha$ production completely.

At $30 \mathrm{~min}$ and $1 \mathrm{~h}$ after LPS injection, TNF- $\alpha$ mRNA production was detectable in spleens by Northern blot (Figure 2). TNF- $\alpha$ mRNA was also expressed at low levels in

A

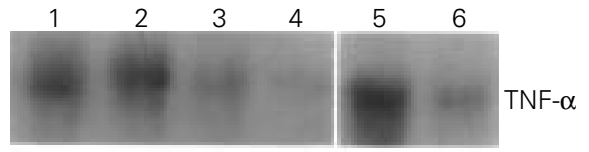

Figure 2 - Northern blot analysis of TNF- $\alpha$ mRNA in spleens of mice injected with $100 \mu \mathrm{g}$ LPS. A, Total RNA was extracted 30 min and $1 \mathrm{~h}$ after LPS injection. Lanes 1, 2 and 5 contain RNA (40 $\mathrm{\mu g} /$ /ane) extracted from spleens of DMSO-treated mice; lanes 3, 4, and 6 contain RNA from spleens of thalidomide- (2 doses of $200 \mathrm{mg} / \mathrm{kg}$ ) treated mice. $B$, Densitometric analysis of the Northern blot. Densitometry was performed using a Phosphorimager. Results are reported as mean \pm one SD of density units for TNF- $\alpha$ normalized to the amount of $\beta$-actin mRNA in DMSO- (open bars) and thalidomide- (hatched bars) treated mice (5 mice per group).

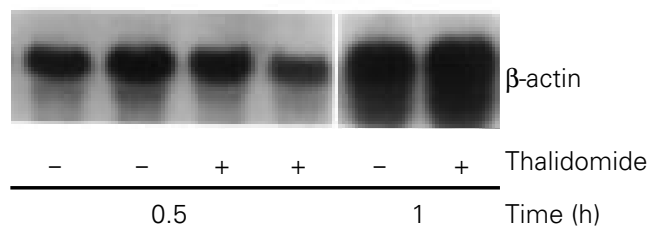

B

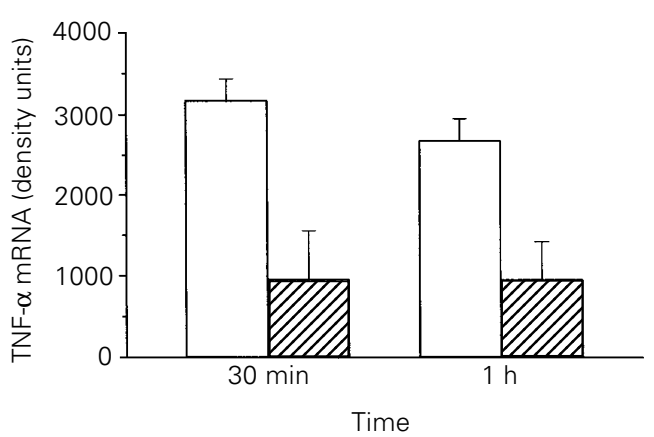

the livers (data not shown). No TNF- $\alpha$ mRNA expression was observed in organs of mice that had not been challenged with LPS (data not shown). Pre-treatment with two doses of $200 \mathrm{mg} / \mathrm{kg}$ thalidomide resulted in a $70 \%$ reduction in TNF- $\alpha$ mRNA levels in the spleens evaluated 30 min after LPS administration. A $65 \%$ reduction in TNF- $\alpha$ mRNA levels was observed $1 \mathrm{~h}$ after LPS challenge (Figure 2).

\section{Effect of thalidomide on LPS-induced cytokines in the mouse}

We also evaluated the effect of thalidomide on the production of other LPS-induced inflammatory cytokines. Serum GMCSF levels peaked at $4 \mathrm{~h}$ and returned to baseline levels at $8 \mathrm{~h}$ after LPS injection; GM-CSF was not significantly affected by thalidomide treatment (Figure 3). Similarly, IFN- $\gamma$ levels peaked in the serum at $8 \mathrm{~h}$ and were also not inhibited by thalidomide treatment. IL-10 peaked in the serum $1.5 \mathrm{~h}$ after the administration of LPS. In the presence of thalidomide, a significant increase in the level of this cytokine was observed ( $\mathrm{P}=$ $0.02)$. Although thalidomide treatment did not modify the serum levels of IL- $61.5 \mathrm{~h}$ after LPS injection, when TNF- $\alpha$ inhibition was maximal, a $50 \%$ reduction in serum IL6 levels was observed $4 \mathrm{~h}$ after LPS injection in thalidomide-treated mice (Figure 3).

IL-1ß mRNA was detected in the spleens at $30 \mathrm{~min}$ after LPS injection, peaked at $1 \mathrm{~h}$ and was still detectable in the spleens $4 \mathrm{~h}$ after LPS injection. There was no significant inhibition in the expression of IL- $1 \beta$ mRNA in thalidomide-treated mice (Figure 4). We could not detect mRNA expression for IL-10 and IFN- $\gamma$ in the spleens of mice injected with LPS, with or without thalidomide treatment.

\section{LPS-mediated endotoxic shock}

Having demonstrated a significant inhi- 


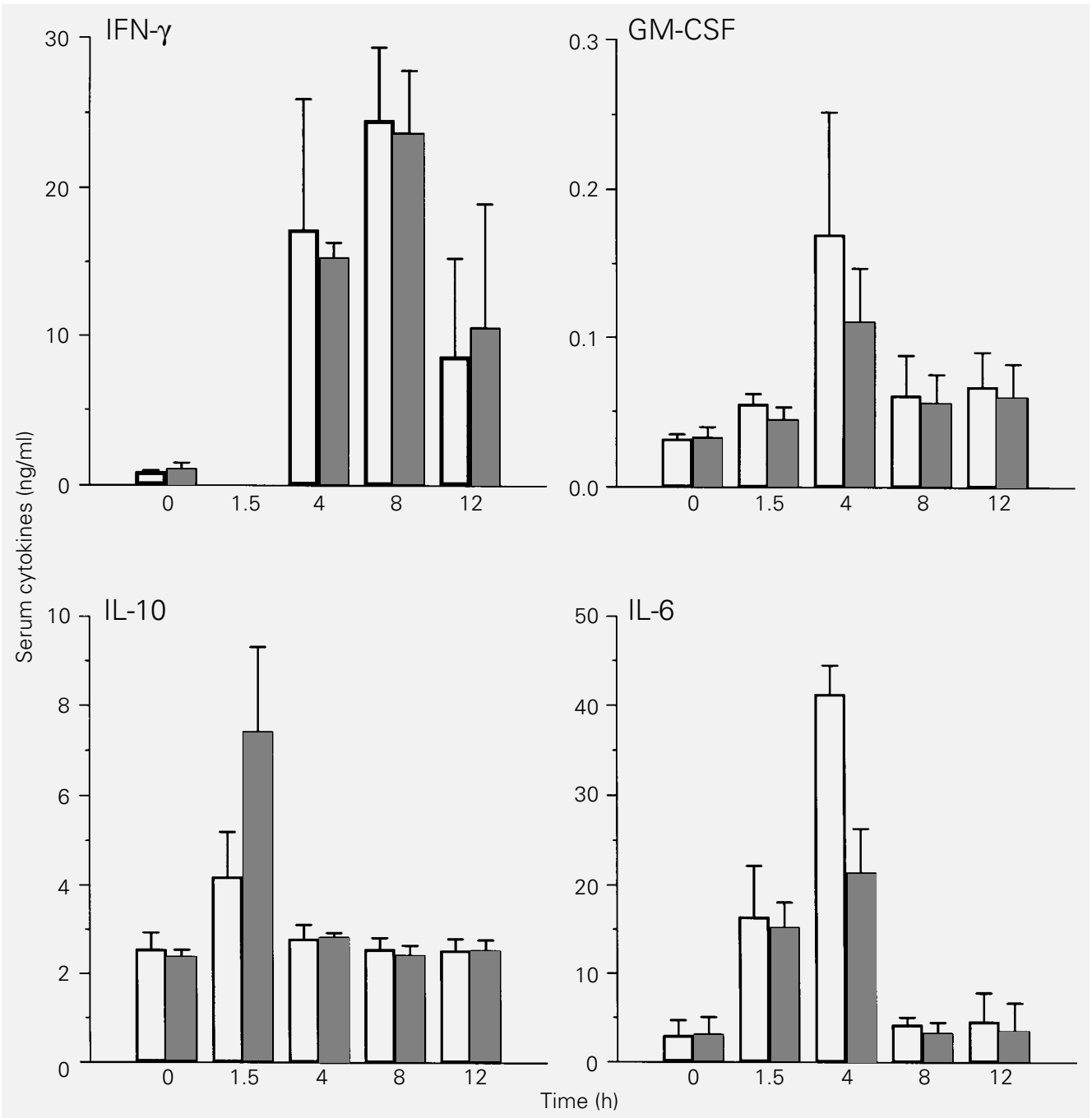

bition of TNF- $\alpha$ production by thalidomide, and the additional changes in cytokine production described above, we next evaluated the effects of the drug on the survival of animals following LPS-induced shock. DMSO-treated mice injected with LPS became lethargic, and developed pilo-erection and diarrhea. The severity of symptoms and the extent of survival of mice was dependent on the LPS dose used (Figure 5). Control mice began to die 24-48 $\mathrm{h}$ after LPS injection. After $72 \mathrm{~h}$ there were no further changes in the lethality curve. At higher doses of LPS, death was recorded as early as $24 \mathrm{~h}$ (Figure 5B). The $\mathrm{LD}_{50}$ for LPS in these experiments ranged from 150 to $250 \mu \mathrm{g}$ LPS per mouse. Mice treated with thalidomide had no diarrhea. Although these animals developed somnolence, they could be more easily aroused than the DMSO-treated control mice. Thalidomide $(200 \mathrm{mg} / \mathrm{kg})$ given $18 \mathrm{~h}$ and $2 \mathrm{~h}$ before the injection of 150 and $200 \mu \mathrm{g}$ LPS protected mice from death $(\mathrm{P}=$ 0.03 for LPS injection of $150 \mu \mathrm{g} / \mathrm{mouse}$ and $\mathrm{P}=0.04$ for doses of $200 \mu \mathrm{g} / \mathrm{mouse})$. The individual response of mice to LPS varied widely from experiment to experiment. At higher doses of LPS (250-300 $\mu \mathrm{g} /$ mouse) thalidomide treatment was not protective $(\mathrm{P}>0.05)$, but was associated with a delay in death. These results suggest that at the higher doses of LPS thalidomide may not be an
Figure 3 - Serum cytokine levels of B6D2/F1 mice challenged with $100 \mu \mathrm{g}$ LPS. Blood was collected at different times after LPS injection and cytokine levels were measured by ELISA for IFN- $\gamma$ (6 mice per group), GMCSF (10 mice per group), IL-10 (10 mice per group), and IL-6 (10 mice per group). Open bars represent DMSO-treated control mice and filled bars represent thalidomide- $(2$ doses of $200 \mathrm{mg} / \mathrm{kg}$ ) treated mice. 
Figure 4 - Northern blot analysis of IL-1ß mRNA expression in spleens of mice injected with $100 \mu \mathrm{g}$ LPS. A, Total RNA was extracted at 1 and $4 \mathrm{~h}$ after LPS injection. Each lane contains 40 $\mu \mathrm{g}$ of total RNA extracted from spleens of DMSO-treated mice (lanes 1 and 3) or RNA from spleens of thalidomide- (2 doses of $200 \mathrm{mg} / \mathrm{kg}$ ) treated mice (lanes 2 and 4). B, Densitometric analysis of the Northern blot. Densitometry was performed using a Phosphorimager. Results are reported as mean \pm SD of IL1 density units normalized to the amount of $B$-actin mRNA in DMSO-treated (open bars) and thalidomide-treated (hatched bars) mice (3 mice per group).
A

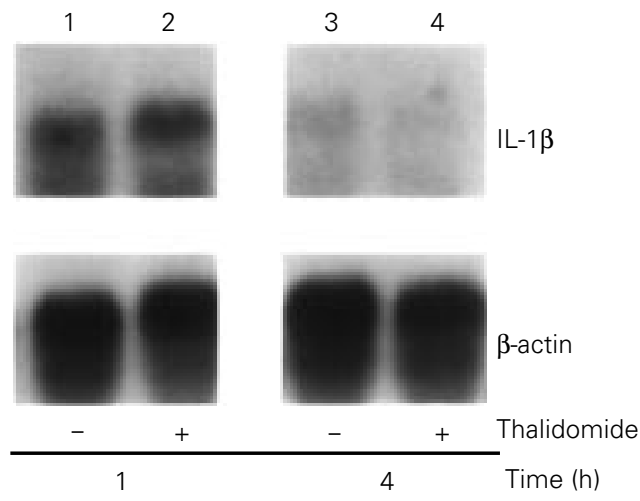

B

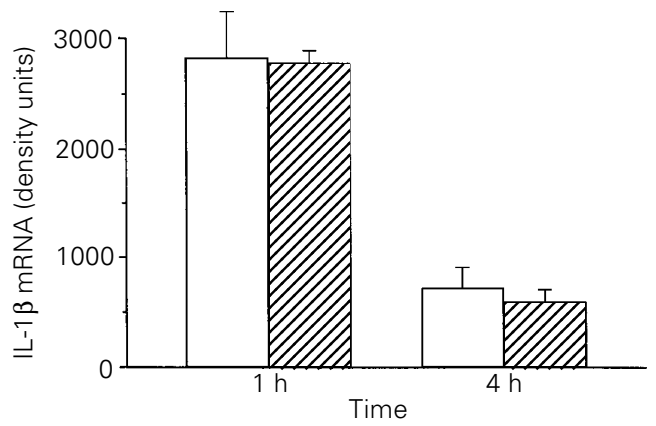

efficient enough drug for protection from the sequelae of LPS-induced cytokine production and shock.

\section{Discussion}

Thalidomide was initially developed and used as a sedative without the knowledge of its mechanism of action or teratogenic effects. Recently, the drug has been shown to inhibit the production of TNF- $\alpha$ by reducing the half-life of the TNF- $\alpha$ mRNA in LPSstimulated human monocytes (15) without directly affecting the production of other cytokines produced by monocytes. Thalidomide is insoluble in water and alcohol, and is very unstable in aqueous solutions. Studies on the pharmacokinetics of thalidomide are not available in the mouse; in a rabbit model, however, treatment of the animals with two or three doses of $150 \mathrm{mg} / \mathrm{kg}$ thalidomide improved absorption and accumulation of the drug in the serum (20). Peak serum levels obtained after three injections of $150 \mathrm{mg} / \mathrm{kg}$ thalidomide (20) are similar to those obtained in humans treated with thalidomide for graft-versus-host disease (21). In our experiments, the need to use two doses of 200 $\mathrm{mg} / \mathrm{kg}$ thalidomide to achieve cytokine modulation may reflect the poor solubility and bioavailability of the drug (22). In fact, in our experiments thalidomide crystals were seen in the peritoneal cavity of the animals after injections of the drug. Based on these considerations, the animals were pre-loaded with thalidomide at doses adequate for sedation, thereby indicating effective pharmacological levels.

The present study demonstrates that administration of thalidomide to mice modified the cytokine response to the intravenous injection of LPS. The drug suppressed TNF$\alpha$ and IL- 6 production and enhanced the production of IL-10. However, thalidomide does not affect IL-6 production in LPS-stimulated monocytes in vitro $(15,19)$. Indeed, following treatment with thalidomide, no inhibition of serum IL- 6 was observed at 1.5 $\mathrm{h}$, when TNF- $\alpha$ inhibition was maximal. We did observe a $50 \%$ reduction in serum IL-6 levels at $4 \mathrm{~h}$ after LPS injection. This temporal relationship suggests that the effect of thalidomide on IL- 6 may be secondary to the inhibition of TNF- $\alpha$ production. Since it has been shown that TNF- $\alpha$ up-regulates IL-6 production (23), a reduction in the level of TNF- $\alpha$ may account for the lower levels of IL-6 observed at the later time point in our studies. Indeed, in animals treated with antibodies against TNF- $\alpha$, a reduction in IL- 6 and IL-1 production in response to bacteremia has also been observed (23).

Thalidomide-treated mice had a consistent elevation in serum IL-10 levels, although we could not detect IL-10 mRNA in the organs of LPS-injected mice whether or not mice were treated with thalidomide. The inhibition of TNF- $\alpha$ and IL- 6 production 
observed in thalidomide-treated mice could be secondary to the enhancement of IL-10 production, since IL-10 has been shown to down-modulate the production of TNF- $\alpha$ and other inflammatory cytokines $(24,25)$. However, in an in vitro system, thalidomide inhibited TNF- $\alpha$ production in the presence of neutralizing antibodies to IL-10, thus confirming that thalidomide has a direct effect on the inhibition of TNF- $\alpha$ production (19). This inverse relationship of TNF- $\alpha$ and IL10 production in LPS-stimulated macrophages has been previously observed in cells treated with drugs that increase intracellular cAMP levels (26), as well as in mice injected with LPS and treated with cyclosporine in vivo (27). Therefore, the increase in IL-10 levels observed in our experiments may reflect an interference by thalidomide in a regulatory pathway between TNF- $\alpha$ and IL10 . The enhancement of IL-10 production by thalidomide may provide additional benefit in the treatment of inflammatory diseases $(28,29)$.

The inhibition of TNF- $\alpha$ by thalidomide in LPS-challenged mice was also associated with protection from LPS-induced shock and death. This result confirms the importance of TNF- $\alpha$ in the pathophysiology of endotoxic shock. However, the protective effect of thalidomide in preventing death was dependent on the dose of LPS used. Mice could not be protected against very high doses of LPS, despite a measurable inhibition of TNF$\alpha$ production (Figure 1). Endotoxic shock is multifactorial and the reduction in the levels of TNF- $\alpha$ achieved by the drug may not be sufficient for the prevention of death in every case. Cytokines other than TNF- $\alpha$ such as IL-1, IL-6 and IFN- $\gamma(1,7,9,30,31)$, and inflammatory mediators such as nitric oxide (31-34) have been shown to contribute to the development of endotoxic shock and death. Higher doses of LPS might induce other pathways independent of TNF- $\alpha$ in the development of shock in this model.

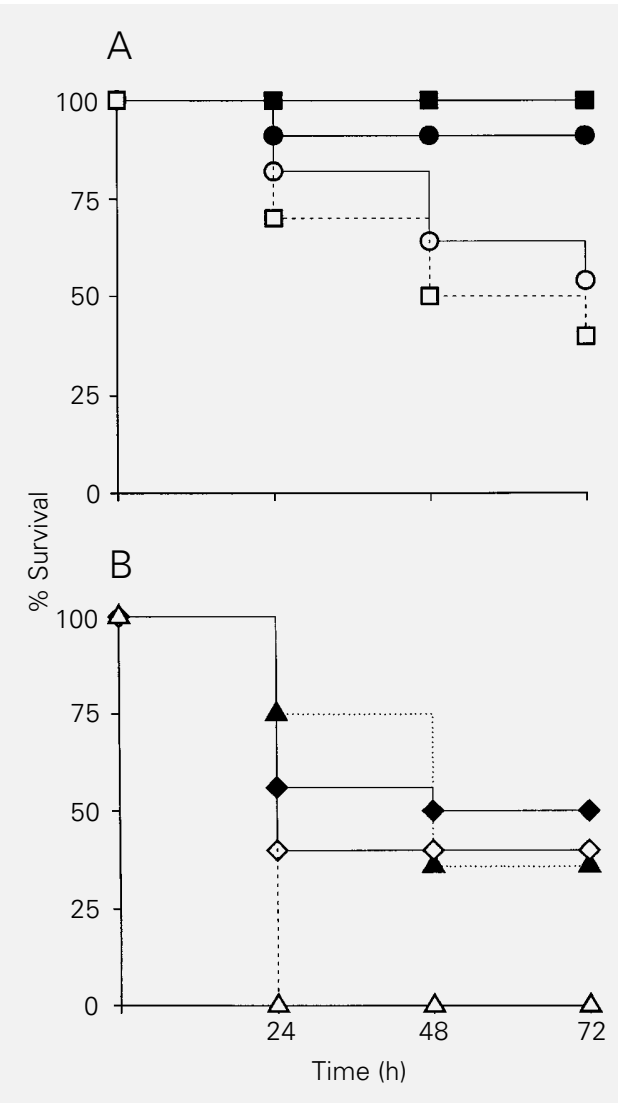

Figure 5 - Survival curve of B6D2/F1 mice injected with different doses of LPS. A, Circles indicate that mice were injected with $150 \mu \mathrm{g}$ of LPS $(11$ mice per group) and squares indicate LPS at $200 \mu \mathrm{g} /$ mouse (14 mice per group). $B$, Doses of LPS were used at $250 \mu \mathrm{g} / \mathrm{mouse}$ (diamonds) (16 mice per group) and $300 \mu \mathrm{g} / \mathrm{mouse}$ (triangles) (8 mice per group). Mice were treated with 2 doses of $200 \mathrm{mg} /$ $\mathrm{kg}$ thalidomide (filled symbols) or DMSO (open symbols) before LPS injection. Occurrence of death was recorded during the 72-h study period.
The use of thalidomide as a TNF- $\alpha$ inhibitor is currently being tested in diseases that are associated with TNF- $\alpha$ toxicity such as wasting observed in AIDS (35). Whether thalidomide can be added to the current arsenal of drugs used for the therapy of endotoxic shock requires further investigation.

\section{Acknowledgments}

We would like to thank Marguerite Nulty for secretarial help, Judy Adams for help in the preparation of the figures, Drs. Patrick Haslett and Victoria Freedman for fruitful discussion during the preparation of this manuscript, Weiguo Ye, Michael Berlowitz, and Ian Henessy for technical help throughout the study, and M. Harper for statistical assistance. 


\section{References}

1. Waage A (1992). Presence and involvement of TNF in septic shock. In: Beutler B (Editor), Tumor Necrosis Factor: The Molecule and the Emerging Role in Medicine. Raven Press, New York, 275-284.

2. Doherty GM, Lange JR, Langstein HN, Alexander HR \& Buresh CM (1992). Evidence for interferon-gamma as a mediator of the lethality of endotoxin and tumor necrosis factor. Journal of Immunology, 149: 1666-1670.

3. Tracey KJ, Beutler B, Lowry SF, Merryweather J, Wolpe S, Milsark IW, Hariri RJ, Fahey 3rd TJ, Zentella A \& Albert JD (1986). Shock and tissue injury induced by recombinant cachectin. Science, 234: 470-474

4. Beutler B, Milsark IW \& Cerami AC (1985). Passive immunization against cachectin/ tumor necrosis factor protects mice from lethal effect of endotoxin. Science, 229: 869-871.

5. Tracey KJ, Fong $Y$, Hesse DG, Manogue KR, Lee AT, Kuo GC, Lowry SF \& Cerami A (1987). Anti-cachectin/TNF monoclonal antibodies prevent septic shock during lethal bacteremia. Nature, 330: 662-664.

6. Pfeffer K, Matsuyama T, Kundig TM, Wakeham A, Kishihara K, Shahinian A, Wiegmann K, Ohashi PS, Kronke M \& Mak TW (1993). Mice deficient for the 55 $\mathrm{kd}$ tumor necrosis factor receptor are resistant to endotoxic shock, yet succumb to L. monocytogenes infection. Cell, 73: 457-467.

7. Ohisson K, Björk $P$, Bergenfeld $M$, Hageman R \& Thompson RC (1990). Interleukin-1 receptor antagonist reduces mortality from endotoxin shock. Nature, 348: 550-552.

8. Alexander HR, Doherty GM, Buresh CM, Venzon DJ \& Norton JA (1991). A recombinant human receptor antagonist to interleukin-1 improves survival after lethal endotoxemia in mice. Journal of Experimental Medicine, 173: 1029-1032.

9. Kamijo R, Le J, Shapiro D, Havell EA, Huang S, Aguet M, Bosland M \& Viloek J (1993). Mice that lack the interferon- $\gamma$ receptor have profoundly altered responses to infection with bacillus Calmette-Guérin and subsequent challenge with lipopolysaccharide. Journal of Experimental Medicine, 178: 1435-1440.

10. Schade FV (1990). Pentoxifylline increases survival in murine endotoxin shock and decreases formation of tumor necrosis factor. Circulatory Shock, 31: 171181.
11. Zabel P, Schade FV \& Schlaak M (1993) Inhibition of endogenous TNF formation by pentoxifylline. Immunobiology, 187 447-463.

12. Silverstein R, Turley BR, Christoffersen CA, Johnson DC \& Morrison DC (1991). Hydrazine sulfate protects D-galactosamine-sensitized mice against endotoxin and tumor necrosis factor/cachectin lethality: Evidence of a role for the pituitary. Journal of Experimental Medicine, 173 357-365.

13. Mohler KM, Sleath PR, Fitzner JN, Cerretti DP, Aldreson M, Kerwar SS, Torrance DS, Otten-Evans C, Greenstreet T, Weerawarna K, Kronheim SR, Petersen M, Gehart M, Kozlosky CJ, March CJ \& Black RA (1994). Protection against a lethal dose of endotoxin by an inhibitor of tumour necrosis factor processing. Nature, 370 : 218-220.

14. Sampaio EP, Sarno EN, Galilly R, Cohn ZA \& Kaplan G (1991). Thalidomide selectively inhibits tumor necrosis factor alpha production by stimulated human monocytes. Journal of Experimental Medicine, 173: 699-703.

15. Moreira AL, Sampaio EP, Zmuidzinas A, Frindt P, Smith KA \& Kaplan G (1993). Thalidomide exerts its inhibitory action on tumor necrosis factor alpha by enhancing mRNA degradation. Journal of Experimental Medicine, 177: 1675-1680

16. Fisch H \& Gifford GE (1983). In vitro production of rabbit macrophage tumor cell cytotoxin. International Journal of Cancer, 32: 105-112.

17. Gunning $P$, Okayama $\mathrm{H}$, Engles J, Blau H $\&$ Kedes $L$ (1983). Isolation and characterization of full-length cDNA clones for human $\alpha-\beta$ - and $\gamma$-actin mRNA: Skeletal but not cytoplasmic actins have an amino terminal cysteine that is subsequently removed. Molecular and Cellular Biology, 3: 787-795.

18. Remick DG, Strieter RM, Eskaudari MK, Nguyen DT, Genord MA, Raiford CL \& Kunkel SL (1990). Role of tumor necrosis factor- $\alpha$ in lipopolysaccharide-induced pathologic alterations. American Journal of Pathology, 136: 49-60.

19. Corral LG, Muller GW, Moreira AL, Chen Y, Wu M, Stirling D \& Kaplan G (1996). Selection of novel analogs of thalidomide with enhanced tumor necrosis factor $\alpha$ inhibitory activity. Molecular Medicine, 2 : 506-515.
20. Burroughs MH, Tsenova-Berkova L, Sokol K, Ossig J, Tuomanem E \& Kaplan G (1995). Effect of thalidomide on the inflammatory response in cerebrospinal fluid in experimental bacterial meningitis. Microbial Pathogenesis, 19: 245-255.

21. Heney D, Norfolk DR, Wheeldon J, Bailey CC, Lewis IJ \& Barnard DL (1991). Thalidomide treatment for chronic graft-versushost disease. British Journal of Haematology, 78: 23-27.

22. Zwingenberger K \& Wnendt S (1996). Immunomodulation by thalidomide: Systemic review of the literature and of unpublished observations. Journal of Inflammation, 46: 177-211.

23. Fong $Y$, Tracey KJ, Moldawer LL, Hesse DG, Manogue KB, Kenney JS, Lee AT, Kuo GC, Allison AC, Lowry SF \& Cerami A (1989). Antibody to cachectin/TNF reduces interleukin- $1 ß$ and interleukin- 6 appearance during lethal bacteremia. Journal of Experimental Medicine, 170: 16271633.

24. Ishida $H$, Hastings $R$, Thompson-Snipes $L$ \& Howard M (1993). Modified immunological status of anti-IL-10 treated mice. Cellular Immunology, 148: 371-384.

25. Marchant A, Bruyns $C$, Vandenabeele $P$, Ducarne M, Gerard C, Delvaux A, de Grootte D, Abramowicz D, Velu T \& Goldman M (1994). IL-10 controls IFN- $\gamma$ and TNF production during experimental endotoxemia. European Journal of Immunology, 24: 1167-1171.

26. Platzer $C$, Meisel $C$, Vogt $K$ \& Volk HD (1994). Up-regulation of monocytic IL-10 by tumor necrosis factor- $\alpha$ and CAMP elevating drugs. International Immunology, 7: 517-523.

27. Durez P, Abramowicz D, Gerard C, Van Mechelen M, Amraoui Z, Dubois C, Leo O, Velu T \& Goldman M (1993). In vivo induction of interleukin-10 by anti-CD3 monoclonal antibody or bacterial lipopolysaccharide: Differential modulation by cyclosporin A. Journal of Experimental Medicine, 177: 551-555.

28. Gerard C, Bruyns C, Marchant A, Abramowicz D, Vandenabeele P, Delvaux A, Fiers W, Goldman M \& Velu T (1993). Interleukin 10 reduces the release of tumor necrosis factor and prevents lethality in experimental endotoxemia. Journal of Experimental Medicine, 177: 547-550.

29. Howard M, Muchamuel T, Andrade S \& Menon S (1993). Interleukin 10 protects mice from lethal endotoxemia. Journal of Experimental Medicine, 177: 1205-1208. 
30. Calandra T, Baumgartner JD, Grau GE, Wu MM, Lambert PH, Schellekens J, Verhoef J \& Glauser MP (1990). Prognostic values of tumor necrosis factor/ cachectin, interleukin-1, interferon-alpha and interferon-gamma in the serum of patients with septic shock. Journal of Infectious Diseases, 161: 982-987.

31. Bucala R (1994). MIF, a previously unrecognized pituitary hormone and macrophage cytokine, is a pivotal mediator in endotoxic shock. Circulatory Shock, 44: 35-39.
32. Petros K, Bennett D \& Vallance P (1991). Effect of nitric oxide synthase inhibitors on hypotension in patients with septic shock. Lancet, 338: 1557-1558.

33. Kilbourn RG, Jubran A, Gross AA, Griffith OW, Levi R, Adams J \& Lodato RF (1990). Reversal of endotoxin-mediated shock by $\mathrm{N}^{\mathrm{G}}$-methyl-L-arginine, an inhibitor of nitric oxide synthesis. Biochemical and Biophysical Research Communications, 172: 1132-1139.
34. Nava E, Palmer RMJ \& Moncada S (1991) Inhibition of nitric oxide synthesis in septic shock: How much is beneficial? Lancet, 338: 1555-1556.

35. Klausner DJ, Freedman VH \& Kaplan G (1996). Thalidomide as an anti-TNF- $\alpha$ inhibitor: Implications for clinical use. Clinical I mmunology and Immunopathology, 81: 1-5. 